\title{
POWER AND PROTEST
}




\title{
RESEARCH IN SOCIAL MOVEMENTS, CONFLICTS, AND CHANGE
}

\author{
Series Editor: Lisa Leitz
}

\section{Recent Volumes:}

Volume 24: Consensus Decision Making, Northern Ireland and Indigenous Movements, Edited by Patrick G. Coy

Volume 25: Authority in Contention, Edited by Daniel J. Myers and Daniel M. Cress

Volume 26: Edited by Patrick G. Coy

Volume 27: Edited by Patrick G. Coy

Volume 28: Edited by Patrick G. Coy

Volume 29: Pushing the Boundaries: New Frontiers in Conflict Resolution and Collaboration, Edited by Rachel Fleishman, Catherine Gerard and Rosemary O'Leary

Volume 30: Edited by Patrick G. Coy

Volume 31: Edited by Patrick G. Coy

Volume 32: Critical Aspects of Gender in Conflict Resolution, Peacebuilding, and Social Movements, Edited by Anna Christine Snyder and Stephanie Phetsamay Stobbe

Volume 33: Media, Movements, and Political Change, Edited by Jennifer Earl and Deana A. Rohlinger

Volume 34: Nonviolent Conflict and Civil Resistance, Edited by Sharon Erickson Nepstad and Lester R. Kurtz

Volume 35: Advances in the Visual Analysis of Social Movements, Edited by Nicole Doerr, Alice Mattoni and Simon Teune

Volume 36: Edited by Patrick G. Coy

Volume 37: Intersectionality and Social Change, Edited by Lynne M. Woehrle

Volume 38: Edited by Patrick G. Coy

Volume 39: Protest, Social Movements, and Global Democracy since 2011: New Perspectives, Edited by Thomas Davies, Holly Eva Ryan and Alejandro Peña 
Volume 40: Narratives of Identity in Social Movements, Conflicts and Change, Edited by Landon E. Hancock

Volume 41: Non-State Violent Actors and Social Movement Organizations: Influence, Adaptation, and Change. Edited by Julie M. Mazzei

Volume 42: Edited by Patrick G. Coy

Volume 43: Bringing Down Divides: Special Issue Commemorating the Work of Gregory Maney (1967 - 2017). Edited by Lisa Leitz and Eitan Alimi 
This page intentionally left blank 
RESEARCH IN SOCIAL MOVEMENTS, CONFLICTS, AND CHANGE VOLUME 44

\title{
POWER AND PROTEST: HOW MARGINALIZED GROUPS OPPOSE THE STATE AND OTHER INSTITUTIONS
}

\author{
EDITED BY \\ LISA LEITZ \\ Chapman University, USA
}

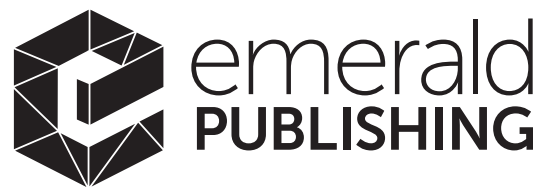

United Kingdom - North America - Japan India - Malaysia - China 
Emerald Publishing Limited

Howard House, Wagon Lane, Bingley BD16 1WA, UK

First edition 2021

Copyright $(C 2021$ by Emerald Publishing Limited

All rights of reproduction in any form reserved.

\section{Reprints and permissions service}

Contact: permissions@emeraldinsight.com

No part of this book may be reproduced, stored in a retrieval system, transmitted in any form or by any means electronic, mechanical, photocopying, recording or otherwise without either the prior written permission of the publisher or a licence permitting restricted copying issued in the UK by The Copyright Licensing Agency and in the USA by The Copyright Clearance Center. Any opinions expressed in the chapters are those of the authors. Whilst Emerald makes every effort to ensure the quality and accuracy of its content, Emerald makes no representation implied or otherwise, as to the chapters' suitability and application and disclaims any warranties, express or implied, to their use.

\section{British Library Cataloguing in Publication Data}

A catalogue record for this book is available from the British Library

ISBN: 978-1-83909-835-2 (Print)

ISBN: 978-1-83909-834-5 (Online)

ISBN: 978-1-83909-836-9 (Epub)

ISBN: 0163-786X (Series)

\section{ISOQAR certified}

Management System,

awarded to Emerald

for adherence to

Environmental

standard

ISOQAR

ISO 14001:2004. 
For my precious family:

My parents David and Judy Hassall, and my sister Jane.

Katayoun and our sons Hyde and Thomas. 
This page intentionally left blank 


\section{CONTENTS}

About the Authors xi

List of Contributors xiii

Introduction to Power and Protest, RSMCC Volume 44

Lisa Leitz and Paige N. Gulley

\section{SECTION I \\ THEORIZING THE POWER OF PROTESTORS}

The Reclamation Master Frame: A Visual Study of the Arab

Uprisings

Mounira M. Charrad, Amina Zarrugh and Hyun Jeong Ha

Understanding Strikes in the 21 ${ }^{\text {ST }}$ Century: Perspectives from the United States

Chris Rhomberg and Steven Lopez

Group Size and the Use of Violence by Resistance Campaigns:

A Multilevel Study of Resistance Method

Christopher J. Cyr and Michael Widmeier

Marginalization and Mobilizing Power in Nonviolent Social Movements

Selina Gallo-Cruz

\section{SECTION II \\ POWER OF INSTITUTIONS AND TRADITION}

Illegitimacy, Political Stability, and the Erosion of Alliances:

Lessons from the End of Apartheid in South Africa

Eric W. Schoon and Robert J. VandenBerg 
Whaling in Korea: Heritage, Framing, and Contention against International Norms

Bradley Tatar

Mobilizing for Religious Freedom: Educational Opportunity Structures and Outcomes of Conservative Christian Campus Activism

Jonathan S. Coley

Epilogue: Updates to Research in Social Movements, Conflicts, and Change

Lisa Leitz

Index 


\section{ABOUT THE AUTHORS}

Mounira M. Charrad ( $\mathrm{PhD}$, Harvard University) is an Associate Professor of Sociology at the University of Texas-Austin. Her book, States and Women's Rights: The Making of Postcolonial Tunisia, Algeria and Morocco, won national awards. Her articles have appeared in major scholarly journals. Her current research focuses on secular feminists and authoritarianism in Tunisia.

Jonathan S. Coley received his PhD in Sociology from Vanderbilt University and is an Assistant Professor of Sociology at Oklahoma State University. His research focuses on social movements, politics, religion, and sexuality. His first book, Gay on God's Campus, was published by the University of North Carolina Press in 2018.

Christopher J. Cyr is an Associate Research Scientist at OCLC. His research looks at how public and private services are provided to communities in several contexts. Christopher holds a PhD in Political Science from the University of Colorado, and he is also a Senior International Fellow at the World Engagement Institute.

Selina Gallo-Cruz is Associate Professor of Sociology at College of the Holy Cross. Her research has been published in European Journal of Cultural and Political Sociology, Interface, Social Movement Studies, Sociology Compass, Sociological Forum, and other volumes. In Political Invisibility and Mobilization, Selina examines women's movements against war.

Paige N. Gulley has an MA in War \& Society from Chapman University. She has written on French colonialism in Algeria, and she enjoys studying colonial theory, hermeneutics, and the lives of women in nontraditional fields. Her current research focuses on female recreation workers during World War II.

Hyun Jeong $\mathrm{Ha}(\mathrm{PhD}$, University of Texas-Austin) is an Assistant Professor of Sociology at Duke Kunshan University, China. Her research focuses on the experience of sectarianism among Christian minorities in Egypt. Her work has appeared in Ethnic and Racial Studies and on the blog of the Baker Institute, Rice University.

Lisa Leitz is the Delp-Wilkinson Professor and Department Chair of Peace Studies at Chapman University. Her book, Fighting for Peace: Veterans and Military Families in the Anti-Iraq War Movement, won the 2015 American Sociological Association's Peace, War and Social Conflict Outstanding Book 
Award. She serves as the Series Editor of Research in Social Movements, Conflicts, and Change.

Steven H. Lopez is an Associate Professor of Sociology at the Ohio State University. His research focuses broadly on work, labor, employment, and society. He has studied and written about auto work, route sales, union organizing, and nursing home work. His current work focuses on experiences of precarity and unemployment.

Chris Rhomberg is a Professor of Sociology at Fordham University. His research focuses on historical and contemporary issues of labor, race, urban development and politics in the United States. He is the author of The Broken Table: The Detroit Newspaper Strike and the State of American Labor (Russell Sage, 2012).

Eric W. Schoon is Assistant Professor of Sociology at The Ohio State University. His interests include political sociology, social movements, comparative historical sociology, culture, and research methods. His work has appeared in outlets including the Journal of Politics, Social Forces, Sociological Methods \& Research, Social Problems, and Sociological Science.

Bradley Tatar, Associate Professor in UNIST, is a cultural anthropologist who has researched revolutionary movements in Latin America. Presently based in South Korea, he researches social movements that are changing human interactions with nature. His publication includes Transnational Frontiers of Asia and Latin America since 1800 (with Jaime Moreno Tejada).

Robert J. VandenBerg is an assistant professor of criminal justice at Norwich University - The Military College of Vermont. His work focuses on violent extremism and contentious politics, and he is the author most recently of "Legitimating Extremism: A Taxonomy of Justifications for Political Violence," published in Terrorism and Political Violence.

Michael Widmeier is a $\mathrm{PhD}$ candidate in Political Science at the University of North Texas. He also serves as an Adjunct Assistant Professor at Webster University in the History, Politics, \& International Relations Department. His research interests include civil conflict, political violence, rebel group organization, social movements, and terrorism.

Amina Zarrugh (PhD, University of Texas-Austin) is an Assistant Professor of Sociology at Texas Christian University. Her research focuses on politics and forced disappearance in North Africa and race/ethnicity in the United States. Her work has appeared in Ethnic and Racial Studies and The Journal of North African Studies. 


\section{LIST OF CONTRIBUTORS}

Mounira M. Charrad

Jonathan S. Coley

Christopher J. Cyr

Selina Gallo-Cruz

Paige N. Gulley

Hyun Jeong $\mathrm{Ha}$

Lisa Leitz

Steven H. Lopez

Chris Rhomberg

Eric W. Schoon

Bradley Tatar

Robert J. VandenBerg

Michael Widmeier

Amina Zarrugh
Department of Sociology, University of Texas-Austin, USA

Department of Sociology, Oklahoma State University, USA

OCLC, USA

Department of Sociology and Anthropology, College of the Holy Cross, USA

Department of History, Chapman University, USA

Division of Social Sciences, Duke Kunshan University, China

Department of Peace Studies, Chapman University, USA

Department of Sociology, The Ohio State University, USA

Department of Sociology and Anthropology, Fordham University, USA

Department of Sociology, The Ohio State University, USA

Division of General Studies, UNIST, Korea School of Justice Studies and Sociology, Norwich University - The Military College of Vermont, USA

Department of Political Science, University of North Texas, USA

Department of Sociology and Anthropology, Texas Christian University, USA 